\title{
La rappresentazione del restauro. Quale ruolo per il disegno documentativo di un intervento conservativo
}

Francesca Gasparetto

Laura Baratin

Abstract

A partire dallo studio e dall'analisi di cosa significa rappresentare un'architettura e più nel dettaglio cosa significa rappresentare il suo restauro, il lavoro si interroga su quale sia il ruolo del disegno nell'ambito della documentazione di un intervento conservativo sui beni culturali. Il contributo prova a declinare l'utilizzo del disegno quale strumento in grado di supportare e contemporaneamente semplificare il processo documentativo per gli interventi di restauro di opere mobili. Dalla rappresentazione grafica alla sua standardizzazione, la documentazione di oggetti di piccole dimensioni deve individuare un suo ruolo specifico, partendo dall'interrogarsi su quali siano gli strumenti e le strategie più idonee all'obiettivo conservativo.

Parole chiave

conservazione, intervento di restauro, documentazione digitale, standard grafici, rappresentazione standardizzata.

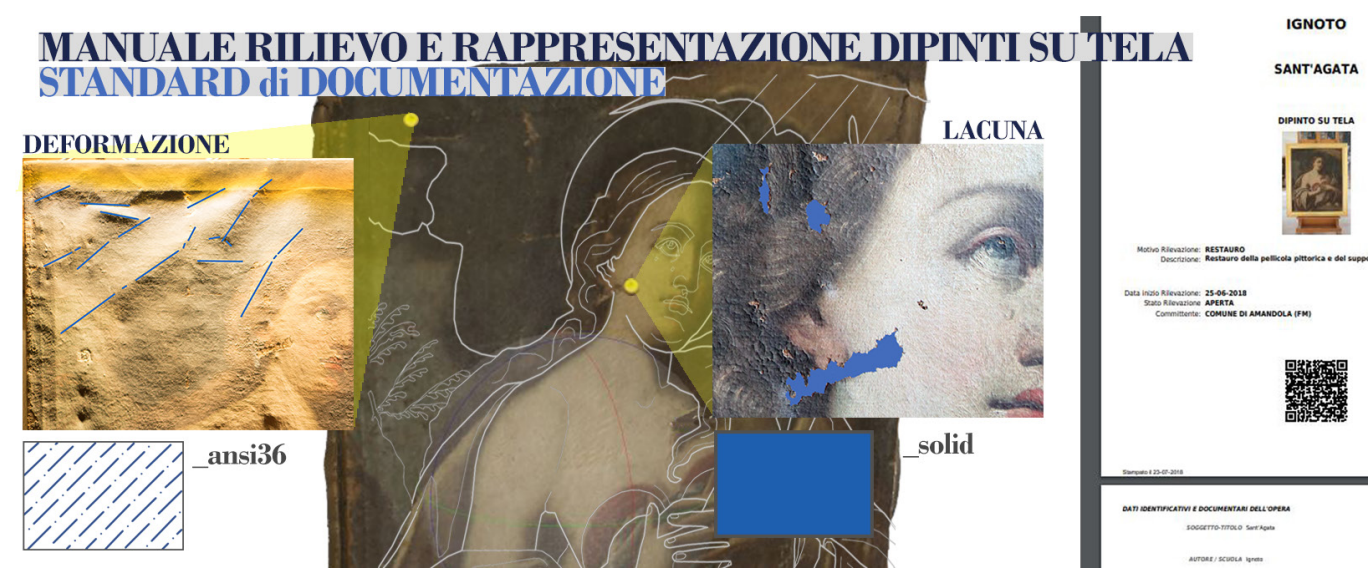




\section{Introduzione}

"Il disegno è quella cosa che tutti credono di saper fare ma che nessuno sa cosa sia. II disegno è la capacità di gestire una quantità d'informazioni, di sensazioni, di percezioni attraverso un segno, il massimo di sintesi possibile" [Migliari 2004, p. I2].

La problematica del disegno utilizzato come strumento documentativo interessa oggi il campo del restauro dei beni culturali mobili, che ancora non ha individuato e sperimentato approcci idonei alle sue necessità di catalogazione e rappresentazione. Nei laboratori di restauro spesso si fa fatica a integrare al processo di analisi la disciplina del disegno, poiché si sottovalutano i valori formativi che aiutano a capire il funzionamento di un oggetto [Docci, Migliari 1992].

Per quel che riguarda le architetture, a partire dal primo step di rilievo della fabbrica, il disegno gioca un ruolo fondamentale e richiede determinate tecniche rappresentative per la restituzione dei dati raccolti, trovandosi a essere il linguaggio con cui si comunica un progetto [Migliari 20I2].

Dunque, qual è la funzione contemporanea della rappresentazione legata al restauro? Come sviluppare una mappa che abbia caratteristiche idonee alla lettura di informazioni tipiche di oggetti mobili? Tenendo in considerazione i due quesiti, il contributo getta le basi teoriche per l'individuazione di rigorose linee guida che portino a un linguaggio grafico codificato. Nel tentativo di assorbire per osmosi i risultati ottenuti da una ricerca strutturata e approfondita proveniente dal campo dell'architettura, si cerca di definire un metodo rappresentativo, che dalle misurazioni alle mappature del degrado sappia comunicare attraverso un disegno scientificamente riconosciuto e rigorosamente codificato. A partire da questo parziale risultato, si è tentato di sviluppare un prototipo di documentazione conservativa, in grado di organizzare le informazioni connesse a un intervento di restauro.

\section{Lineamenti per un approccio alla teoria della rappresentazione di beni mobili}

In alcuni casi, fino a oggi, si è cercato di applicare i metodi architettonici ai beni mobili, quali dipinti su tela o legno, sculture e arredi, installazioni contemporanee senza sviluppare un vero e proprio metodo applicativo (figg. I, 2). II risultato è stata la produzione di dossier

Fig. I. Esempio di tavola impaginata senza standardizzazione (element dipinto su tela)

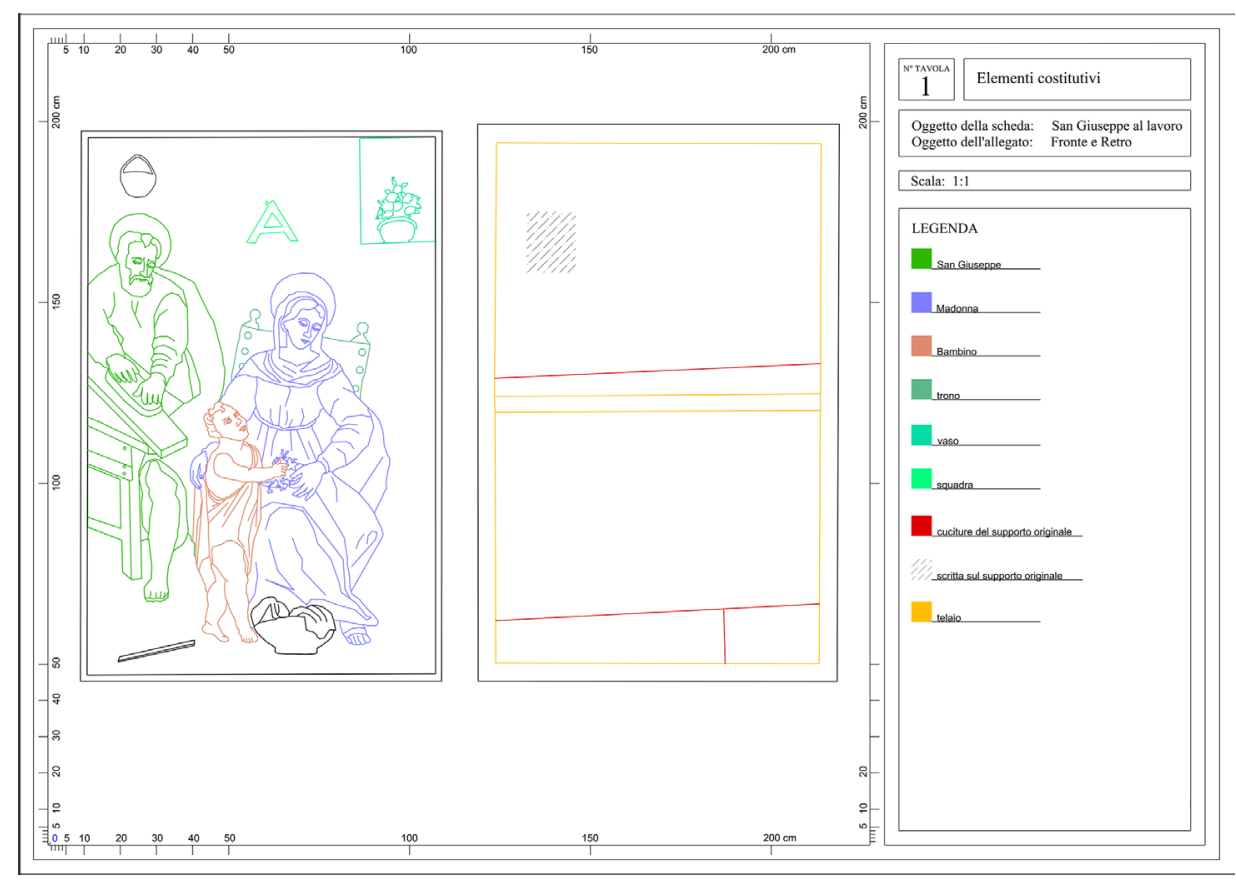


grafici utilizzati solo per gli scopi amministrativi/burocratici e non come reale base pratica per una progettazione integrata e condivisa dalle diverse figure professionali che collaborano al progetto conservativo. Le schede di restauro depositate negli archivi riportano schemi grafici spesso realizzati dopo l'intervento e a completamento della documentazione da consegnare agli enti di tutela. Questo atteggiamento di rinuncia è dovuto alla difficoltà di riconoscere al disegno un ruolo analitico e di intenderlo come supporto temporaneo della mente [De Rubertis 1994]. Un approccio diverso potrebbe riconoscere al disegno un ruolo di studio e lo inserirebbe nella categoria delle indagini conoscitive come strumento interpretativo, così come è avvenuto in architettura.

La disciplina dell'architettura ha da sempre dato molto spazio all'indagine riguardante i metodi rappresentativi, poiché proprio gli strumenti grafici hanno permesso di individuare un linguaggio comune in grado di oggettivare visioni soggettive, dal rilievo dell'esistente al progetto del nuovo [Docci et al. 20 I I]. Gli esercizi teorici portati avanti da ricercatori e studiosi ci permettono di pensare al disegno come uno strumento operativo in grado di descrivere geometricamente, mappare, modellare e narrare [Salerno $20 \mathrm{l} \mathrm{I}$ ]; uno strumento non solo in grado di trascrivere la realtà, ma un'attività complessa che permette a un'idea di essere comunicata [Colistra $20 \mathrm{l} \mathrm{I].} \mathrm{Facendo} \mathrm{riferimento} \mathrm{al} \mathrm{binomio} \mathrm{conoscenza/rappresentazione,}$ il disegno non è solo restituzione acritica dei dati registrati in fase di rilievo o rappresentazione veloce e semplificata delle linee generali di un oggetto [D'Acunto 20 I2]. Partendo da questa affermazione si può individuare il corretto campo d'azione e definire l'obiettivo della ricerca che il restauratore deve impostare.

Se per i progettisti il disegno svolge dunque diversi ruoli, basandosi sugli aspetti fondamentali del vedere, pensare, comunicare e ricordare [Docci et al. $20 \mathrm{ll}$ ] e quindi aiuta anche a definire un pensiero creativo, certamente per il restauratore rappresentare ha un obiettivo più specifico. Nel nostro caso il disegnare non ha come unico fine quello di sintetizzare più informazioni possibili in uno spazio ristretto, ma soprattutto quello di sfruttare l'approccio analitico del disegno come strumento primario e imprescindibile. Lo studio, qui presentato, parte dalla mancanza di un percorso sistematico a cui fare riferimento, all'interno di un laboratorio di restauro, nel momento in cui ci si accinge a documentare lo stato di fatto. Per definire le linee guida di un approccio all'opera d'arte di tipo grafico-descrittivo, è quindi necessario analizzare un linguaggio rappresentativo contemporaneo, non si può fare riferimento solo ed esclusivamente alla scienza della rappresentazione tradizionale.

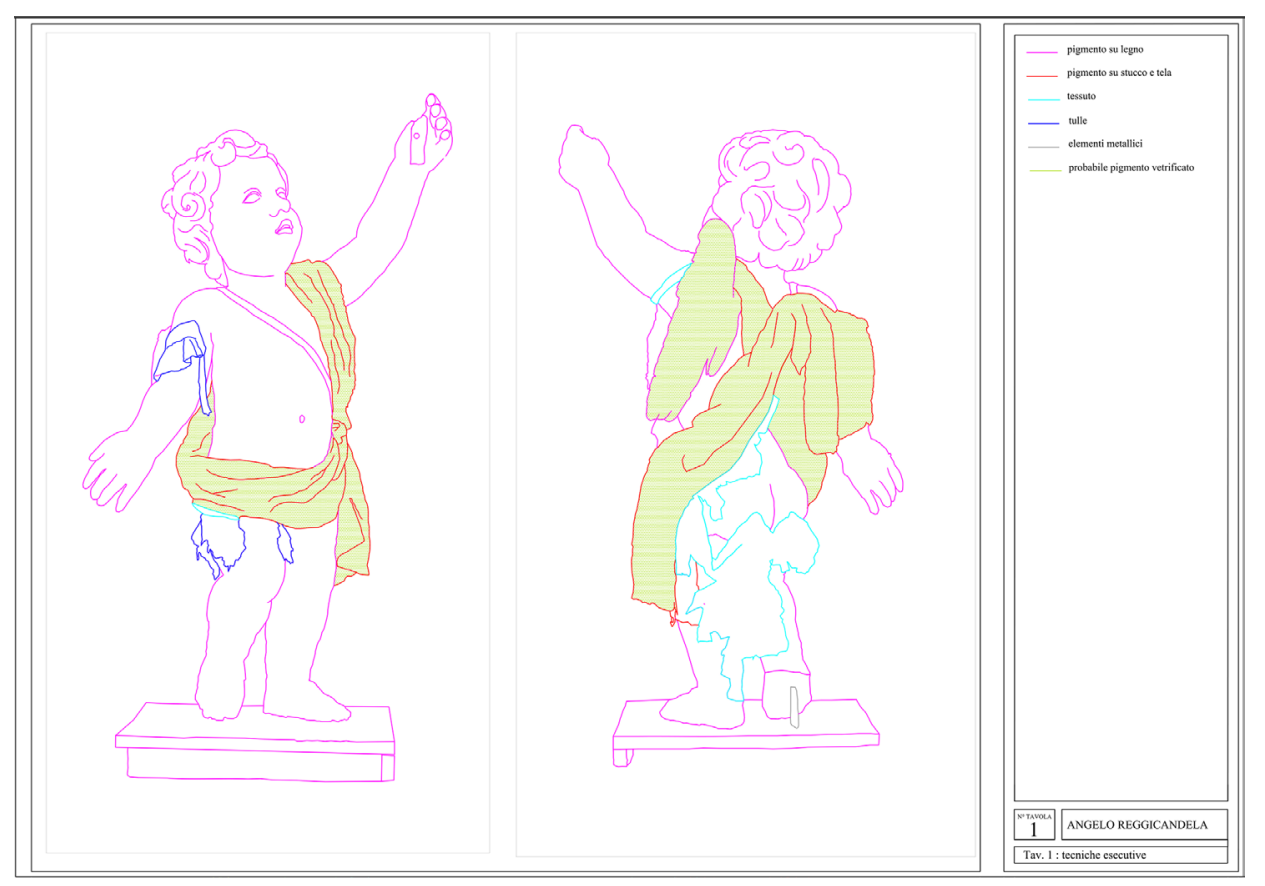


La geometria descrittiva giocava un ruolo fondamentale per la descrizione di uno spazio in un momento in cui la modellazione tridimensionale non esisteva. Era quindi uno strumento indispensabile per rappresentare lo spazio stereometrico su un supporto piano [D'Acunto 20 I4]. II risultato ottenuto era necessariamente l'esito di una rielaborazione grafica della realtà, quindi era necessario attraversare una fase analitica per poter arrivare alla rappresentazione. Oggi le tecnologie contemporanee sono in grado di riprodurre in automatico volumi e ambienti in uno spazio virtuale, potendoli modellare e interpretare. Questa evoluzione ha portato a una visione della disciplina rappresentativa molto più estesa e applicata in maniera molto diversa. L'ambito dei beni culturali mobili ha accolto favorevolmente l'uso di strumenti che riproducono virtualmente l'oggetto nella sua forma originale, senza però individuarne il vero potenziale analitico. Pur non avendo mai applicato da parte del restauratore le ricerche in campo di rappresentazione e comunicazione bidimensionale, sono state invece sperimentate applicazioni indirizzate verso lo studio di modelli utili soprattutto alla fruizione e alla valorizzazione dell'oggetto. L'argomento è rimasto comunque sempre molto lontano dalle competenze di un restauratore che piuttosto collabora con esperti della modellazione 3D al fine di ottenere il prodotto digitale come allegato di una relazione di un suo intervento.

È necessario sottolineare come i modelli 3D, risultato di un'elaborazione tecnica automatica, non sono, nella maggior parte dei casi, un risultato sfruttabile da un punto di vista analitico, ma piuttosto un elemento che arricchisce il lavoro da un punto di vista estetico.

Occorre invertire la tendenza e arrivare a sviluppare una rappresentazione che abbia come obiettivo lo studio, la sistematizzazione di dati utili alla progettazione dell'intervento; per questo motivo sarà necessario che il restauratore stesso sappia interpretare dati dimensionali e geometrici e che conosca gli strumenti per la loro restituzione grafica.

\section{Costruire la documentazione conservativa: note per un'elaborazione ragionata}

Il percorso di rappresentazione che si sta provando a delineare deve avere dunque come risultato la scientificità di un disegno prodotto a partire da un rilievo (digitale o non) e il rigore di un linguaggio definito sulla base di standard universali. La documentazione che un restauratore produce in fase analitica e operativa assume così un valore di immagine materiale, descritta da caratteristiche spaziali, geometriche e cromatiche.

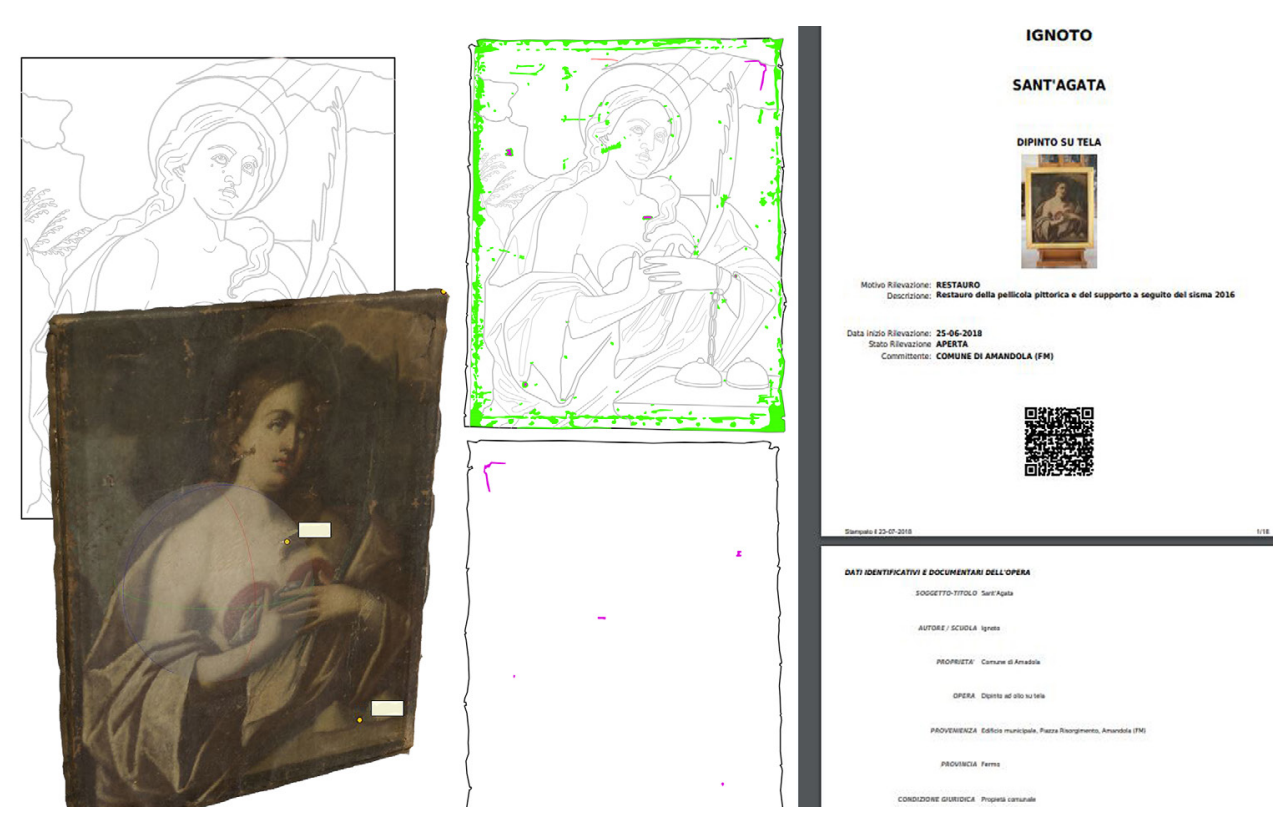


Le informazioni che una documentazione per il restauro di un'opera mobile deve mettere insieme sono molteplici e di varia forma. L'obiettivo deve essere sistematizzarle, al fine di sviluppare una nuova mappa dei dati consultabile. Occorre quindi unire all'interno di uno strumento coerente il risultato del rilievo, la rappresentazione delle tecniche esecutive e dei degradi e le indicazioni riguardanti analisi diagnostiche e quelle infine riguardanti l'intervento. Questi dati sono raccolti e restituiti in maniera molto diversa uno dall'altro e schematizzabili in tre fasi:

I) il rilievo e lo studio della geometria e della morfologia dell'oggetto;

2) la definizione delle tecniche esecutive, l'individuazione dei degradi e il conseguente intervento;

3) la campagna di indagini diagnostiche.

Ognuna delle fasi sopra elencate produce output rappresentativi molto diversi tra loro: un disegno/modello 3D; mappature supportate da immagini; una relazione tecnica accompagnata da grafici e immagini (fig. 3).

La sfida è dunque quella di unire i risultati in un prodotto organico standardizzato di facile consultazione, a partire dal layout della tavola, fino alla scelta delle legende da utilizzare.

II primo step del lavoro è stato l'individuazione delle mappature necessarie: tecniche esecutive (TE), interventi precedenti (IP), stato conservativo (SC), interventi eseguiti (IE).

Facendo un parallelo con i prodotti grafici architettonici (fig. 4), possiamo dire che:

- la tavola TE corrisponde al rilievo architettonico/analisi delle murature;

- la tavola IP corrisponde a fasi costruttive/restauri precedenti;

- la tavola SC corrisponde all' analisi del degrado;

- la tavola IE corrisponde al progetto di intervento.

Tra gli elaborati prodotti dal restauratore, a oggi manca l'informazione fotografica che viene organizzata solo all'interno della relazione tecnica. Nella definizione di un fascicolo grafico diventa necessario l'apparato fotografico, come livello di informazione diretta che facilita la comunicazione.

Per la sperimentazione sono stati coinvolti gli studenti del corso di Disegno [I], giovani aspiranti restauratori che hanno dovuto sviluppare un fascicolo documentativo a partire da documentazione grafica, fotografica e tecnica raccolta e non organizzata da colleghi durante

Fig. 4. Esempio di

rappresentazione grafica per l'architettura stato conservativo e progetto interventi (elaborazione grafica di: C. Frigieri.

Università degli Studi

di Roma "La Sapienza",

Facoltà di Architettura

"Valle Giulia". Relatore:

prof. arch. G. Carbonara

correlatore: prof. arch $\mathrm{C}$ Bellanca).

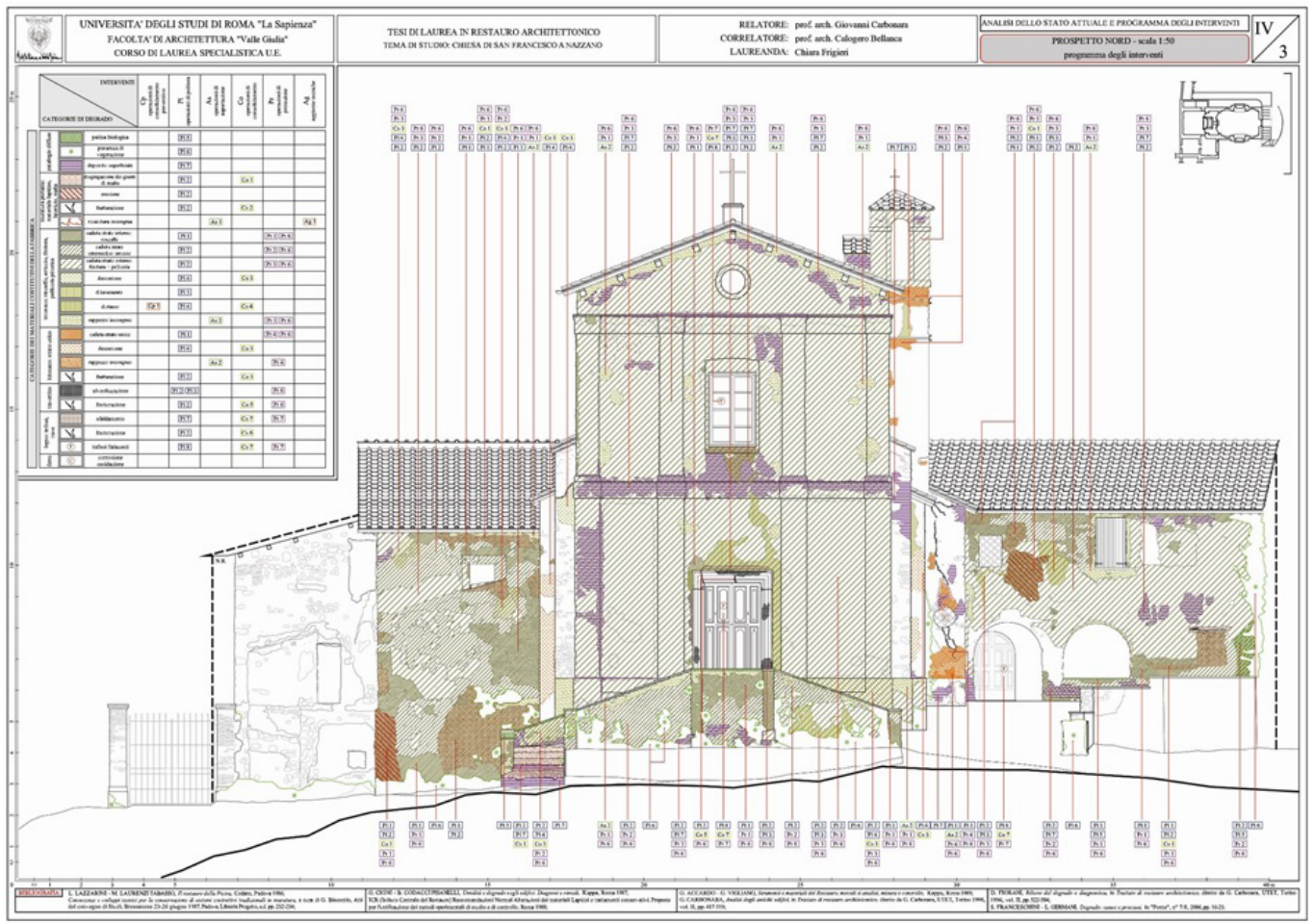


gli anni precedenti. Si è deciso di lavorare, in questa prima fase, su una tipologia di opere, cioè i dipinti su tela e su tavola, per una prima verifica dei risultati su una tipologia omogenea. I dipinti sono stati classificati secondo la loro complessità geometrica, tenendo conto anche delle parti costitutive. In base alle forme geometriche individuate, sono state definite - sulla base delle regole della geometria piana - delle misurazioni standard necessarie a descrivere l'ingombro dell'oggetto. Sono stati quindi realizzati degli schemi-guida di supporto al rilievo diretto (fig. 5). Queste indicazioni di base sono risultate molto importanti al fine di velocizzare le operazioni di misurazione durante sopralluoghi, in cantiere o in laboratorio.

Classificate le tipologie di dipinti in base alla loro complessità geometrica, sono stati progettati dei possibili layout di tavola, organizzati per poter descrivere graficamente le parti di cui è composto l'oggetto artistico (fig. 6).

Fig. 5. Manuale di rilievo e rappresentazione

(indicazioni standard per misurazioni).

\section{MANUALE RILIEVO E RAPPRESENTAZIONE DIPINTI SU TELA | MISURAZIONI}
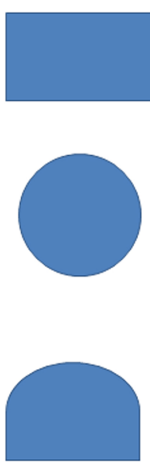

FORME GEOMETRICHE POSSIBILI | TIPOLOGIA OPERA
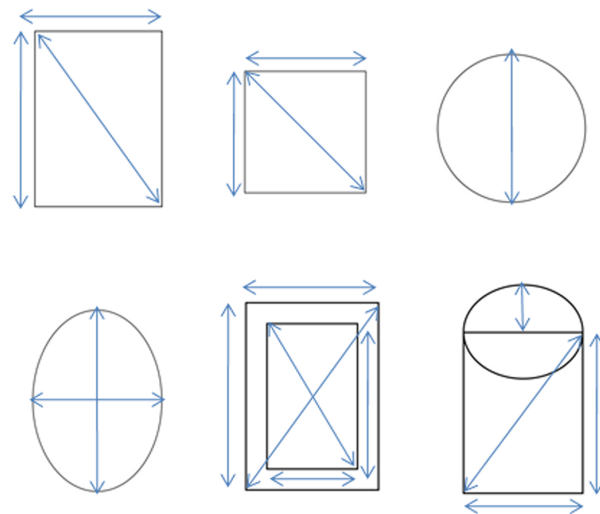

MISURAZIONI FONDAMENTALI

Corso di Disegno 2 | A.A. 2018/2019

\section{MANUALE RILIEVO E RAPPRESENTAZIONE DIPINTI SU TELA | LAYOUT}

numero 1 restituzione grafica BASE GRĀFICA

numero 2 campagna fotografica DOCUMENTTAZIONE FOTO

numero 3 _ info grafiche LEGENDĀ

numero 4 cartiglio

NTESTAZ̄IONETTAVOLA

numero 5 ORcode COLLEGAMENTO SCHEDATURA

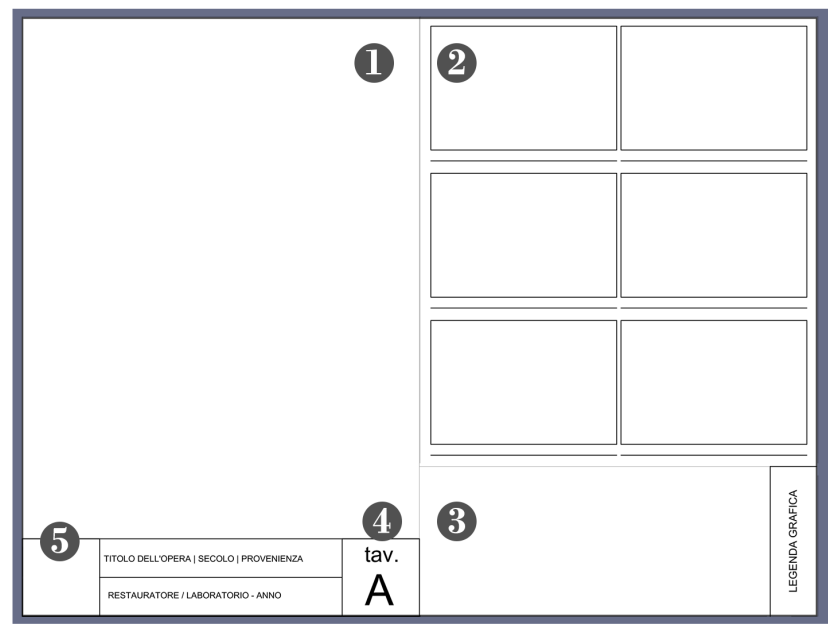

Corso di Disegno 2 | A.A. 2018/2019 
Una volta conclusa la fase di rilievo geometrico, è stato necessario soffermarsi sulla definizione di uno standard che aiutasse nella descrizione delle tecniche esecutive e dei degradi che colpiscono supporti e superfici. Nel 1977 un gruppo di ricercatori - su iniziativa di Giovanni Urbani - definì una proposta grafica descrittiva dei degradi possibili su superfice lapidea (UniNormal). Oggi è diventata la normativa di riferimento per la mappatura di degradi sui materiali lapidei. II lavoro svolto sollecita la necessità di normative anche per manufatti artistici realizzati su altri supporti e prova a delineare una possibile soluzione per i dipinti antichi.

A partire dalla sintetizzazione grafica del degrado per opere dipinte, si sono individuati retini idonei e un colore di riferimento. II grado di intensità utilizzato per la campitura di colore definisce il livello di gravità del degrado $($ figg. 7,8$)$.

\section{MANUALE RILIEVO E RAPPRESENTAZIONE DIPINTI SU TELA | STANDARD GRAFICI}

Fig. 7. Manuale di rilievo e rappresentazione dei dipinti su tela

(sviluppo della proposta di standardizzazione di legenda grafica per
rappresentare i degradi)
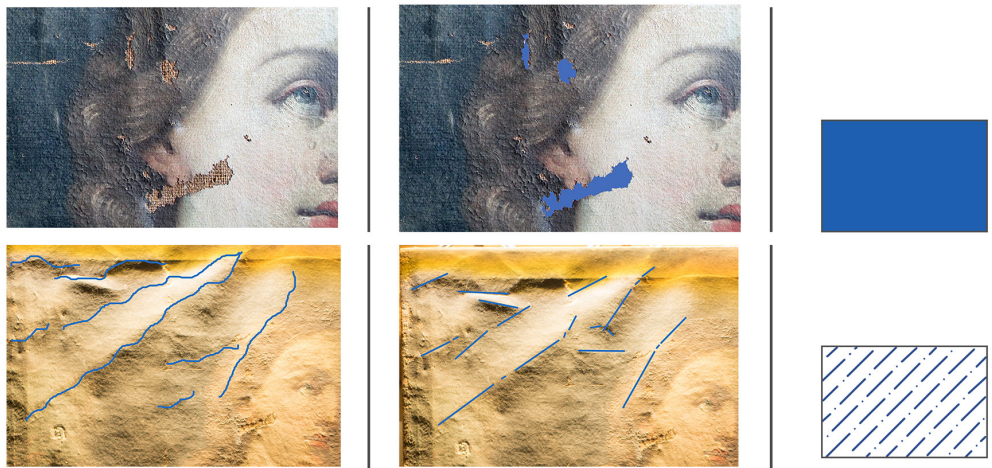

solid
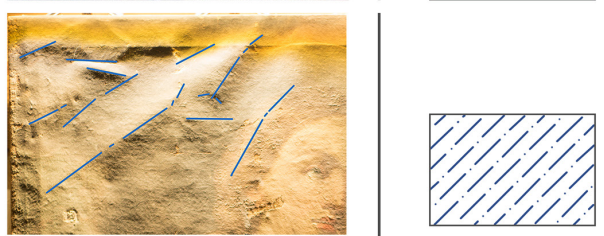

ansi36

DEFORMAZIONE

\section{MANUALE RILIEVO E RAPPRESENTAZIONE DIPINTI SU TELA | STANDARD GRAFICI}
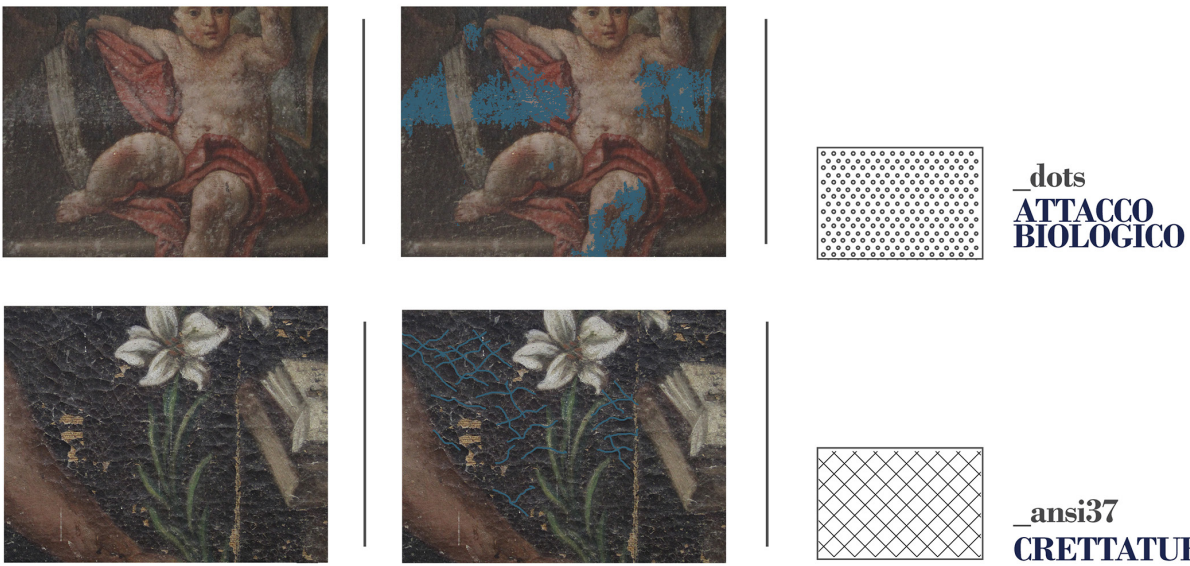

ansi37 CRETTATURA 
Un procedimento simile è stato applicato per la realizzazione di una legenda descrittiva delle tecniche esecutive utilizzando dei retini colorati.

Se fino a questo livello di documentazione è stato possibile far riferimento alla scienza del disegno e alla grafica vettoriale, diverso è l'approccio se si parla di documentazione diagnostica. In questo caso non è sufficiente appoggiarsi alla cultura del progetto visivo, occorre integrare nei nostri grafici e modelli un collegamento diverso e aprire a una documentazione dinamica mutilivello. Lo strumento comunicativo non può essere qui il disegno, ma l'interpretazione di dati scientifici avviene attraverso la parola che aiuta il restauratore a definire cause del degrado e possibili interventi. Questa necessità può venir soddisfatta da un database online che permette il collegamento in tempo reale ai dati messi a disposizione dai diagnosti. Nel nostro caso un QRcode abbinato alla tavola del rilievo permette la consultazione diretta delle indagini microinvasive.

\section{Rappresentare per conservare: la ricerca di uno standard per le opere mobili}

L'architetto usa il disegno per dare forma ai suoi progetti, il restauratore dovrebbe sfruttarne le qualità analitiche e descrittive: l'approccio analitico è il punto di partenza fondamentale per uno studio tecnico dell'oggetto e per la sua reale conoscenza; le possibilità descrittive e comunicative che la scienza della rappresentazione ha in sé sono invece la reale possibilità di rendere sostenibile la disciplina della conservazione nel futuro. Solo comunicando i risultati ottenuti, collocandoli nell'ambito di un territorio accessibile e rendendoli disponibili a chi ogni giorno usufruisce dell'arte potremo dire completata la missione del restauratore. Questo può avvenire solo a fronte di una raccolta dati sistematica, che segua un percorso standardizzato e regolato dalle reali necessità documentative.

Questo studio cerca di colmare il gap metodologico che c'è tra le tecniche tradizionali che non prevedono l'uso di grafici per la sistematizzazione dei dati e l'uso della digitalizzazione che oggi si applica al patrimonio in maniera sempre più massiccia. L'intera sperimentazione può definirsi come il tentativo di individuare un percorso fondamentale, attraverso la didattica, per arrivare al dato digitale coscienti del suo valore culturale.

Quindi, ha senso oggi parlare ancora di disegno applicato alla documentazione degli interventi di restauro sui beni mobili in un contesto in cui le tecnologie digitali rappresentano e documentano molto velocemente ogni step del lavoro? Crediamo di sì. Questo lavoro dimostra come l'utilizzo della teoria tradizionale accostato a un pensiero contemporaneo dinamico e integrato permetta di muovere i primi passi verso un settore, a oggi poco studiato, ma di fondamentale importanza perché riguarda la documentazione del nostro patrimonio identitario.

La radicale inversione di rotta nei confronti di una disciplina spesso dimenticata dai conservatori si può avere solo a partire da nuovi percorsi didattici che riescano a rendere più efficace l'insegnamento delle tecniche rappresentative applicate a un patrimonio in movimento. Questo è possibile tenendo conto della storia della rappresentazione e inglobando l'insegnamento di tecniche informatiche idonee agli obiettivi professionali negli ambiti della conservazione e del restauro.

\section{Note}

[I] Disegno 2 - Scuola di Conservazione e Restauro, Università di Urbino Carlo Bo, A.A. 20 I 8/20I9.

\section{Riferimenti bibliografici}

Colistra Daniele (20 I I). Novanta idee in attesa di Layout. In Salerno Rossella (a cura di). Teorie e tecniche della rappresentazione contemporanea. Sant'Arcangelo di Romagna (RN): Maggioli Editore, 20 I I, pp. I7-32.

D'Acunto Giuseppe, 2012. Complessità e configurazione. Disegno e geometria delle forme architettoniche. Venezia: Geometria Disegno Immagine, Libreria Editrice Cafoscarina.

De Mattia Francesco, Zaccaria, Ambrosi Angelo (1994). Geometria e percezione nei metodi di rappresentazione grafica. Quaderni dell'istituto di disegno-politecnico Bari. Bari: Edipuglia. 
De Rubertis Roberto ( 1994). II disegno dell'architettura. Roma: Carrocci Editore.

Docci Mario, Migliari Riccardo (1992). Geometria Descrittiva e Scienza della rappresentazione. Incontro di studi su geometria e percezione nei metodi di rappresentazione grafica, Bari 23-24 settembre 1992. Bari:Edipuglia.

Docci Mario, Gaiani Marco, Maestri Diego (201 I). Scienza del disegno. Roma: Cittastudi.

Filippa Monica (a cura di) (2012). Elogio della teoria - In praise of theory. Identità delle discipline del disegno e del rilievo - The fundamentals of the disciplines of representation and survey. Atti del $34^{\circ}$ Convegno Internazionale dei Docenti delle Discipline della Rappresentazione. Roma 13- 15 settembre 2012. Roma: Gangemi.

Mazzetti Carlo (1975). Il disegno: analisi di un linguaggio. Castions de mura (UD): La Goliardica.

Migliari Riccardo (2004). Disegno come Modello. Riflessioni sul disegno nell'era informatica. Bologna: Edizioni Kappa.

Migliari Riccardo (20I2). Elogio della teoria - In praise of theory. In Filippa Monica (a cura di) (20I2). Elogio della teoria - In praise of theory. Identità delle discipline del disegno e del rilievo - The fundamentals of the disciplines of representation and survey. Atti del $34^{\circ}$ Convegno Internazionale dei Docenti delle Discipline della Rappresentazione. Roma 13- 5 settembre 20 I2. Roma: Gangemi.

Rossi Michela (2006). Il segno e la forma. Grammatica grafica per l'architettura. Fidenza (PR): Mattioni DRR-Quaderni per la didattica e la ricerca della Facoltà di Architettura.

Russo Jacopo (2008). Degrado dei materiali lapidei: proposta di simbologia grafica. In Carbonara Giovanni. Trattato di restauro architettonico - Secondo aggiornamento. Milano: UTET.

Salerno Rossella (a cura di) (20I I). Teorie e tecniche della rappresentazione contemporanea. Sant'Arcangelo di Romagna (RN): Maggioli Editore.

Spallone Roberta (2012). Rappresentazione e progetto. La formalizzazione delle convenzioni del disegno architettonico. Alessandria: Edizioni dell'Orso.

Strollo Rodolfo Maria (2008). Rappresentazione e formazione. Tra ricerca e didattica. Roma: Aracne editrice.

\section{Autori}

Francesca Gasparetto, Università Politecnica delle Marche, fnc.gasparetto@gmail.com Laura Baratin, Università di Urbino "Carlo Bo", laura.baratin@uniurb.it

Per citare questo capitolo: Gasparetto Francesca, Baratin Laura (2020). La rappresentazione del restauro. Quale ruolo per il disegno documentativo di un intervento conservativo/The representation of restoration process. What role for the documentary drawing of a conservative
intervention. In Arena A., Arena M., Brandolino R.G., Colistra D., Ginex G., Mediati D., Nucifora S., Raffa P. (a cura di). Connettere. Un disegno per intervention. In Arena A., Arena M., Brandolino R.G., Colistra D., Ginex G., Mediati D., Nucifora S., Raffa P. (a cura di). Connettere. Un disegno per
annodare e tessere. Atti del $42^{\circ}$ Convegno Internazionale dei Docenti delle Discipline della Rappresentazione/Connecting. Drawing for weaving relationannodare e tessere. Atti del $42^{\circ}$ Convegno Internazionale dei Docenti delle Discipline della Rappresentazione/Connecting. Drawing
ships. Proceedings of the 42 th International Conference of Representation Disciplines Teachers. Milano: FrancoAngeli, pp. 467-484. 


\section{The Representation of Restoration Process. What Role for the Documentary Drawing of a Conservative Intervention}

Francesca Gasparetto

Laura Baratin

Abstract

Starting from the analysis of the representation of an architecture and in more detail what it means to represent its restoration, the work examines the role of drawing in the documentation of a conservative intervention. The contribution tries to decline the use of drawing as a tool able to support and simplify the documentation process for the restoration of mobile works. From graphic representation to its standardization, the documentation of small objects must identify a specific role, starting from the question of what the most suitable tools and strategies for the conservation objective are.

Keywords

conservation, restoration interventions, digital documentation, graphic standards, standardized representation.

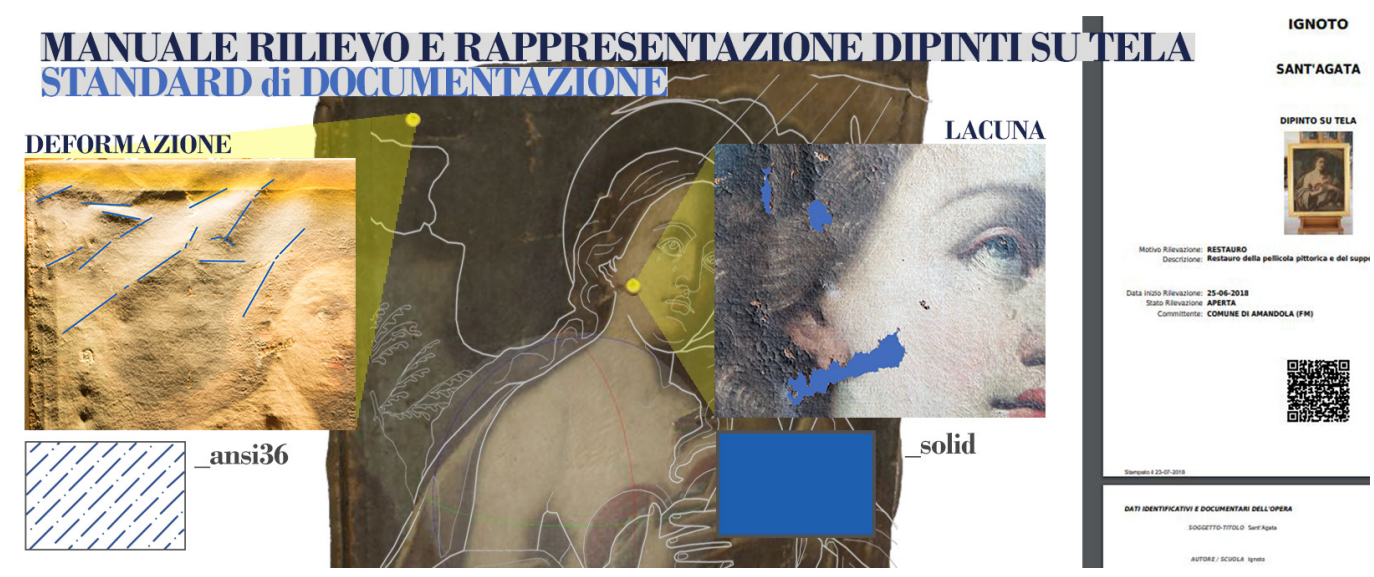




\section{Introduction}

"Il disegno è quella cosa che tutti credono di saper fare ma che nessuno sa cosa sia. II disegno è la capacità di gestire una quantità d'informazioni, di sensazioni, di percezioni attraverso un segno, il massimo di sintesi possibile" [Migliari 2004, p. 12].

The problem of drawing as a documenting tool interest today the field of restoration of movable cultural assets, which has not yet tested approaches to its needs for cataloguing and representation. It is often difficult for restorers to integrate the drawing discipline into the process of analysis, because the educational values that help to understand the functioning of an object are underestimated [Docci, Migliari 1992].

For architecture the drawing plays a fundamental role and requires specific representative techniques for the restitution of collected data, a real language with which a project is communicated [Migliari 20I2].

So, what is the contemporary function of representation linked to restoration? How to develop a map that has characteristics suitable for the reading of information typical of mobile objects? Taking into consideration both aspects, the paper sets the theoretical basis to identify the guidelines that would lead to a coded graphic language. In an attempt to absorb by osmosis the results obtained from an extensive research coming from architecture field, we try to define a representative method, that from measurements to maps of degradation knows how to communicate through a scientifically recognized and rigorously codified drawing. Starting from this partial result, an attempt has been made to develop a prototype of conservative documentation, able to organize the information related to a restoration intervention.

\section{Outlines for an approach to the teory of movable assets representation}

In the cases investigated, architectural methods were applied to movable assets, such as paintings on canvas or wood, sculptures and furniture, contemporary installations with no real application method (figs. I, 2). Thus, graphic dossiers were produced that were used
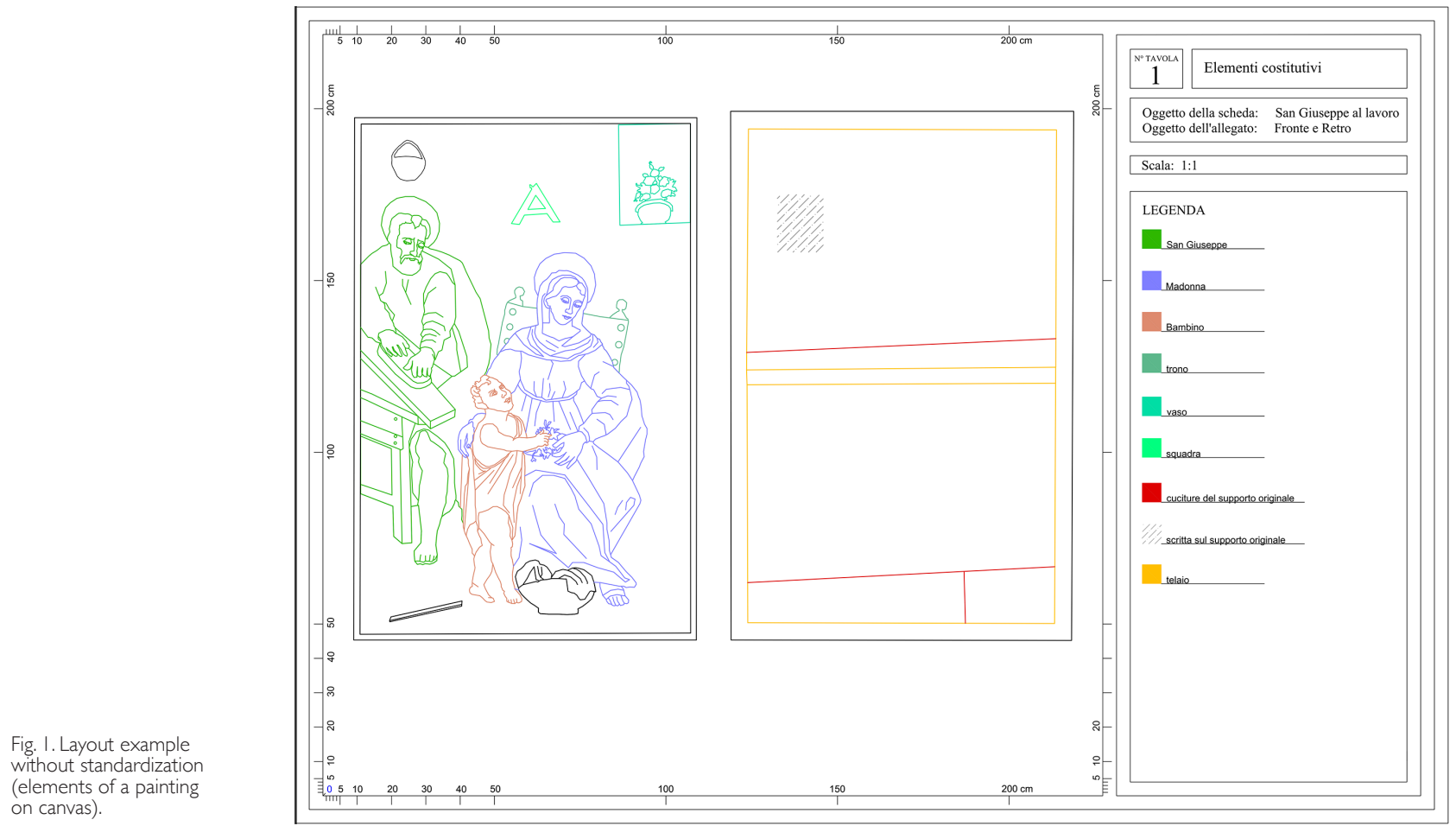
only for administrative/bureaucratic purposes and not as a practical basis for an integrated and shared design for the conservation project. The restoration data in the archives are accompanied by graphic sketch often created only to complete the documentation to be handed over to supervisory. This attitude of renunciation is about difficulty of recognizing the drawing as an analytical role and of understanding it as a temporary support of the mind [De Rubertis 1994]. A different approach could recognize the drawing as a study role and insert it in the category of cognitive investigations as an interpretative tool, as it has happened in architecture.

The discipline of architecture always gives a lot of space to the investigation of representative methods, since graphic tools allow to identify a common language able to objectify subjective visions, from the survey to the new project or [Docci, Maestri 20I I]. The theoretical exercises carried out by researchers and scholars allow us to think of drawing as an operational tool able to describe geometrically, map, model and narrate [Salerno 20 I I]; a tool not only able to transcribe reality, but a complex activity that allows an idea to be communicated [Colistra 20II]. Referring to the binomial knowledge/representation, the drawing is more than an uncritical restitution of data recorded during the survey or a quick simple representation of general object's lines [D'Acunto 20I2]. Starting from this statement it is possible to identify the correct field of action and define the research goal that the restorer must set.

Therefore, for architects, drawing plays different roles, based on the key aspects of seeing, thinking, communicating and remembering [Docci, Maestri 20l I]. The practice of drawing also helps to define creative thinking. For the restorer it has a more specific objective. In our case the aim is not just to synthesize as many information as possible in a limited space, but especially to apply the analytical approach of drawing as a primary and indispensable tool. The study starts from the lack of a systematic path to refer to within a restoration laboratory documenting a state of conservation.

In order to define the guidelines for a graphic-descriptive approach to the artwork, it is therefore necessary to analyse a contemporary representative language. The reference is not only to the traditional science of representation.

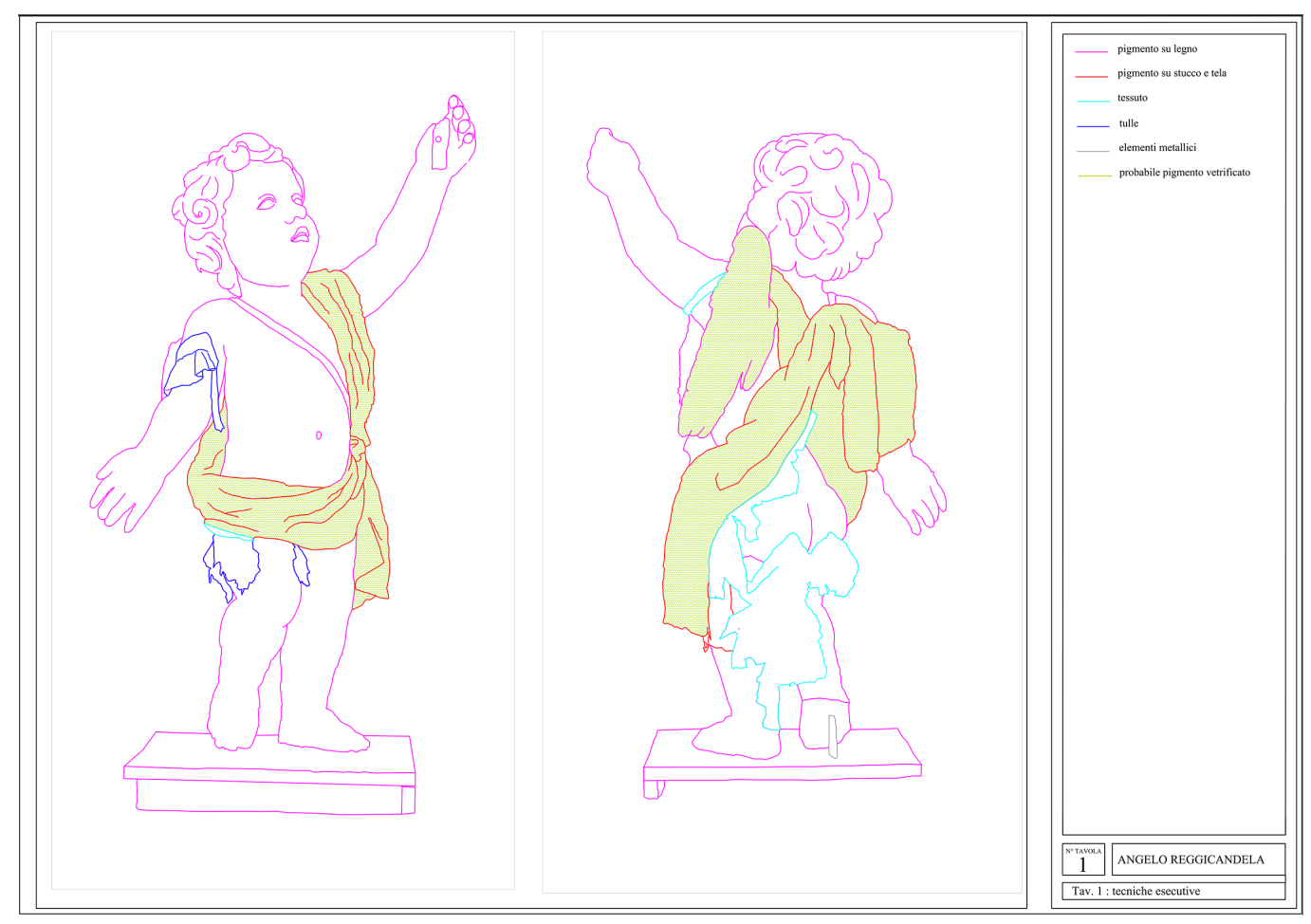


Descriptive geometry played a central role in the space description when three-dimensional modelling did not exist. It was an indispensable tool to represent stereometric space on a plane support [D'Acunto 20I4]. The obtained result was the product of a graphic re-elaboration of reality. The representation was the result of an analytical phase.Today contemporary technologies can automatically reproduce volumes and environments in a virtual space, modelling and interpreting them. This trend has led to a much broader vision of the representative discipline and they applied in a very different way.

The field of movable cultural heritage easily uses tools to virtually reproduce the object in its original form, but without identifying its analytical potential. Although the restorer has never applied research in the field of two-dimensional representation and communication, applications aimed at the study of models useful above all for the fruition and enhancement of the object have been experimented. However, the subject has always remained very far from the expertise of a restorer who rather collaborates with experts in 3D modelling in order to obtain the digital product as an attachment to a report of one of his interventions. In this case it must be said that 3D models, which are the output of automatic technical processing, are not an analytical result, but rather an element that enriches the work from an aesthetic point of view.

It is necessary to reverse the trend and obtain a representation for the study of the object and the systematization of data useful for the design of the intervention; for this reason it will be necessary that the restorer knows how to interpret dimensional and geometric data and that he knows the equipment.

\section{Create the conservative documentation: notes for well-reasoned processing}

The research aims to obtain a scientific drawing produced from a survey (digital or not) and a rigorous and defined language based on universal standards. The documentation produced by a restorer in analytical and operational phases takes on now the value of a material image, described by spatial, geometric and chromatic characteristics.

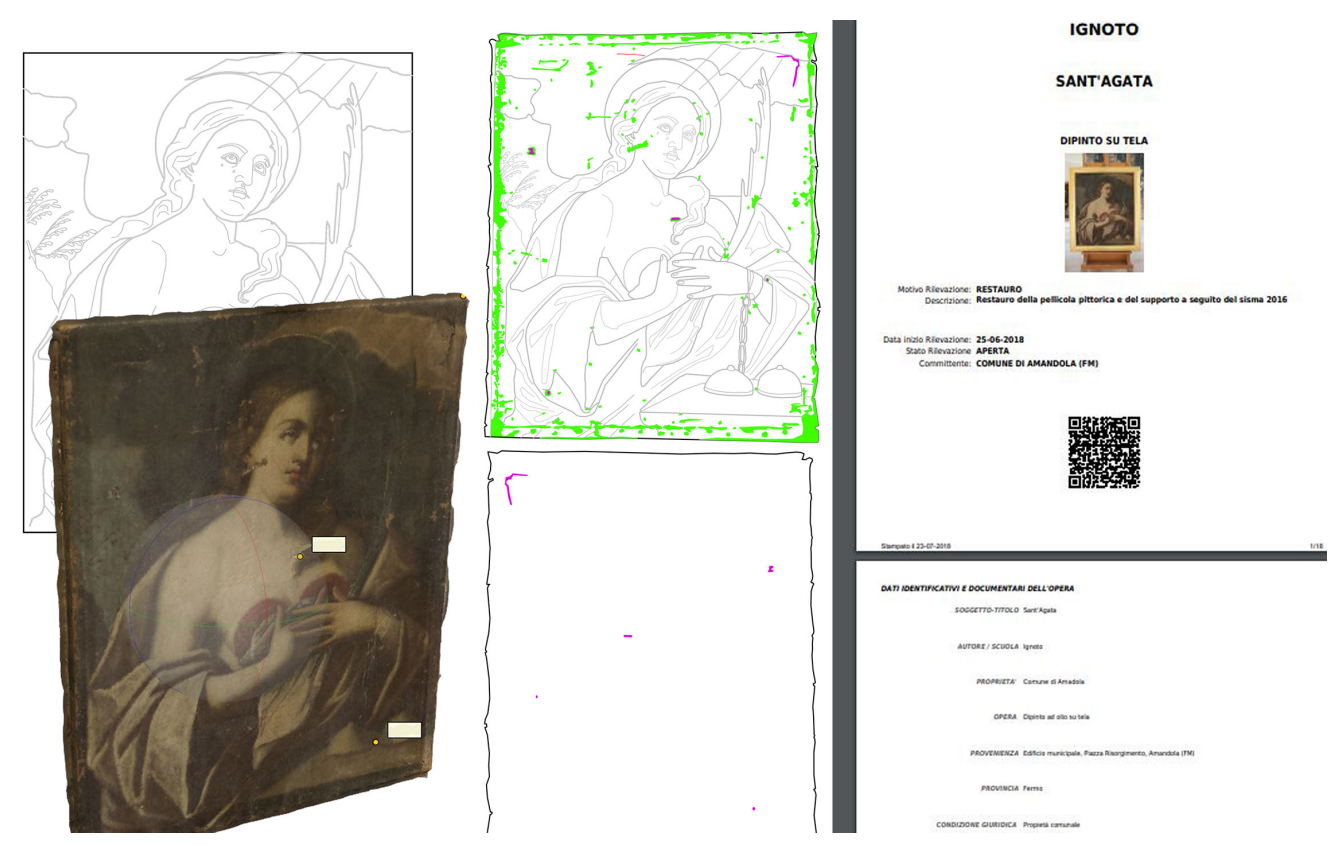


The information that a documentation for the restoration of a mobile object has to put together is multiple and of various forms. The objective must be to systematize them in order to develop a new data map that can be consulted. It is therefore necessary to combine within a coherent tool the result of the survey, the representation of the execution techniques and degradation and the indications concerning diagnostic analysis and those finally concerning the intervention.

Data is collected in different ways one from the other and can be outlined in three steps:

I. the survey and study of the geometry and morphology of the object;

2. the definition of the executive techniques, the identification of the degradation and the consequent intervention;

3. the diagnostic investigation campaigns.

Each of the above listed phases produces very different representative outputs: a 3D drawing/model; mappings supported by images; a technical report accompanied by graphs and images (fig. 3).

Therefore, the challenge is to merge the results into a standardized organic product easy to consult, starting from the layout, up to the choice of the legends to apply.

The first step of the work was the identification of the necessary mappings: executive techniques (ET), previous interventions (PI), conservative state (CS), interventions (IN).

Making a parallel with the architectural graphic products (fig.4), we can say that:

- the ET table corresponds to the architectural survey/analysis of the building;

- the PI table corresponds to previous construction/restoration phases;

- table CS corresponds to the degradation analysis;

- table IN corresponds to the intervention project.

Among the documents produced by the restorer, photographic information, which is only organized within the technical report, is missing today. In the definition of a documentative graphic booklet, the photographic apparatus is necessary as a level of direct information that facilitates communication.

The students of the course Drawing [2], young aspiring restorers/conservators had to develop a documentation file from graphic, photographic and technical documentation collected and not organized by colleagues during the previous years, were involved in the experi-

Fig. 4. Example of graphic representation for architecture - state of conservation and project interventions (graphic elaboration by C. Frigieri. University of Rome "La Sapienza", Faculty of Architecture "Valle Giulia". Supervisor: prof. arch. G. Carbonara,

Correlator: prof. arch. C. Bellanca).

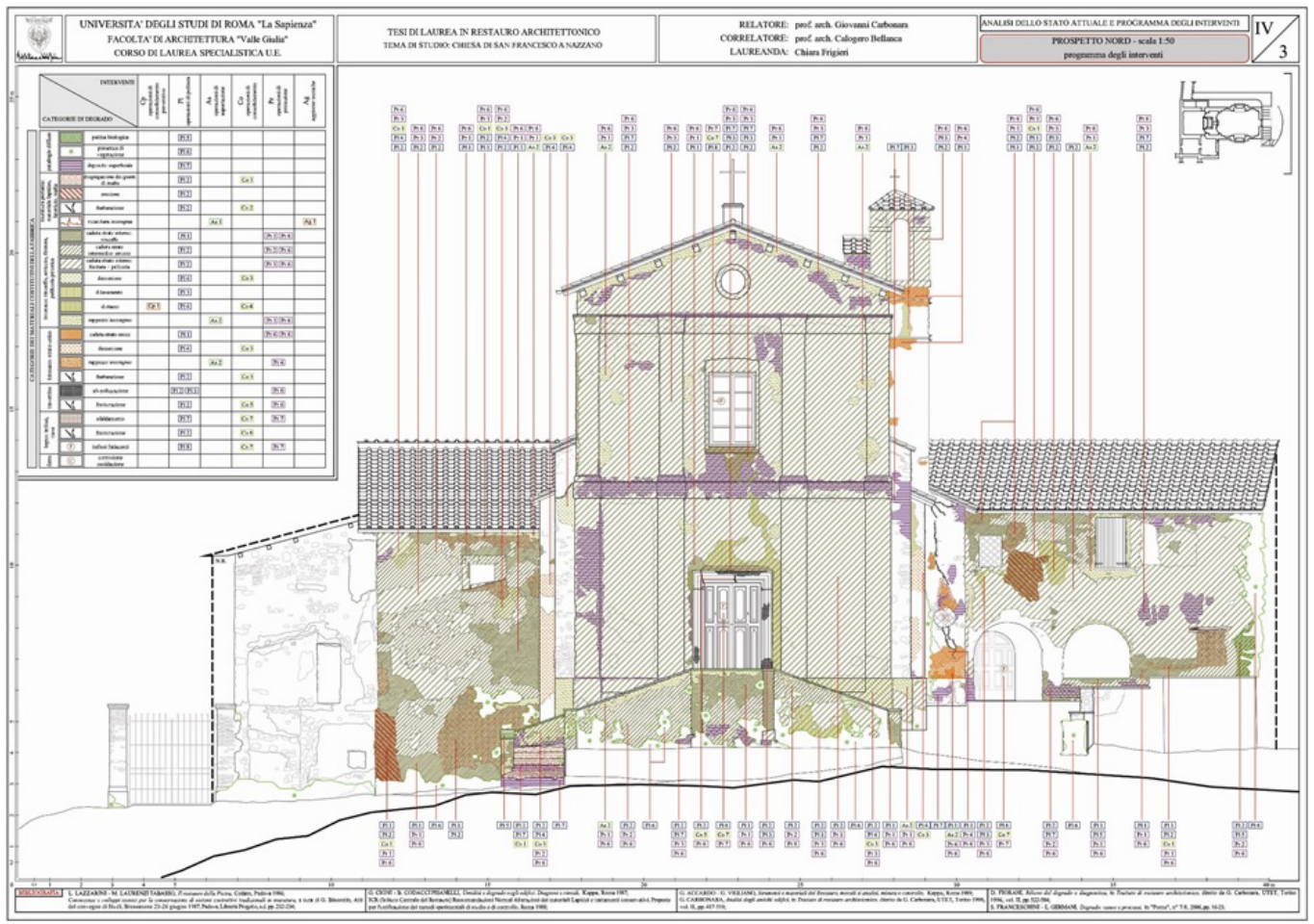


mentation. It was decided to work, in this first phase, on a typology of works, i.e. paintings on canvas and on wood, for a first verification of the results on a homogeneous typology.

The paintings were classified according to their geometric complexity, also taking into account the constituent parts. On the basis of the geometrical shapes identified, standard measurements were defined -based on the rules of plane geometry- necessary to describe the size of the object. Therefore, some guide-diagrams have been realized to support the survey (fig. 5). These basic indications were very important in order to speed up the measurement operations during inspections, on site or in the laboratory.

Once the types of paintings were classified according to their geometric complexity, possible table layouts were designed in order to graphically describe the parts of which the art object is composed (fig. 6).

\section{MANUALE RILIEVO E RAPPRESENTAZIONE DIPINTI SU TELA | MISURAZIONI}
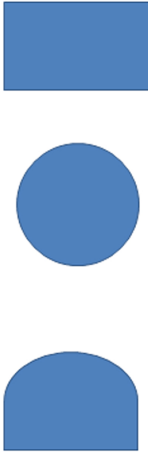

FORME GEOMETRICHE POSSIBILI | TIPOLOGIA OPERA

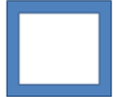

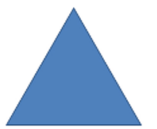
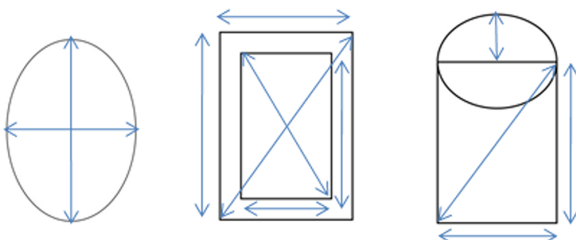

MISURAZIONI FONDAMENTALI

\section{MANUALE RILIEVO E RAPPRESENTAZIONE DIPINTI SU TELA | LAYOUT}

numero 1 restituzione grafica BASE GRĀFICA

2 numero 2 campagna fotografica DOCUMENTTAZIONE FOTO

3 numero 3 info grafiche

numero 4 _ cartiglio INTESTAZ̄IONE TAVOLA

numero 5 QRcode COLLEGAMENTO SCHEDATURA

PROPOSTA LAYOUT tipo A RAPPRESENTAZIONE DEL RILIEVO

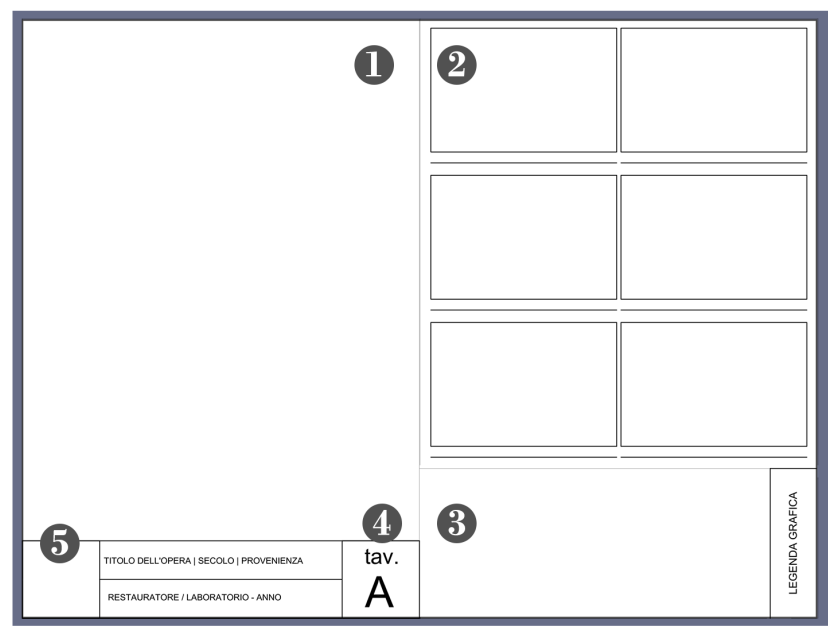

Corso di Disegno 2 | A.A. 2018/2019 
Once the phase of geometrical survey was completed, it was necessary to focus on the definition of a standard that would help in the description of the executive techniques and the degradation affecting supports and surfaces. In 1977 a group of researchers - on Giovanni Urbani's initiative - defined a graphic proposal describing the possible degradation of stone surfaces (UniNormal). Today it has become the reference standard for the mapping of degradation on stone materials. The work carried out encourages the need for standards also for artistic artefacts made and tries to outline a possible solution for ancient paintings. Starting from the graphic synthesis of the degradation for painted works, possible hatches and colours have been identified. The degree of intensity used for colour sampling defines the level of gravity of the degradation (figs. 7, 8).

\section{MANUALE RILIEVO E RAPPRESENTAZIONE DIPINTI SU TELA | STANDARD GRAFICI}
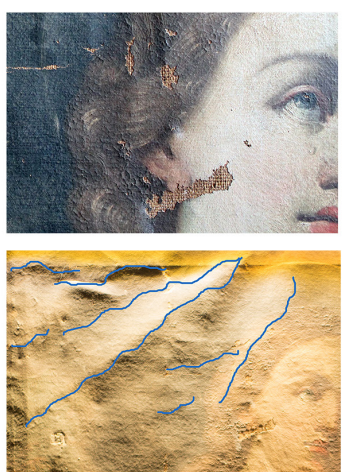
representation

handbook (graphic

standardisation proposa for degradation).
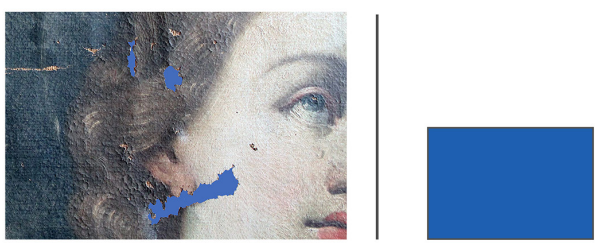

solid
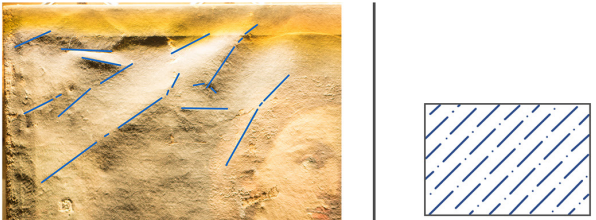

ansi36

DEFORMAZIONE
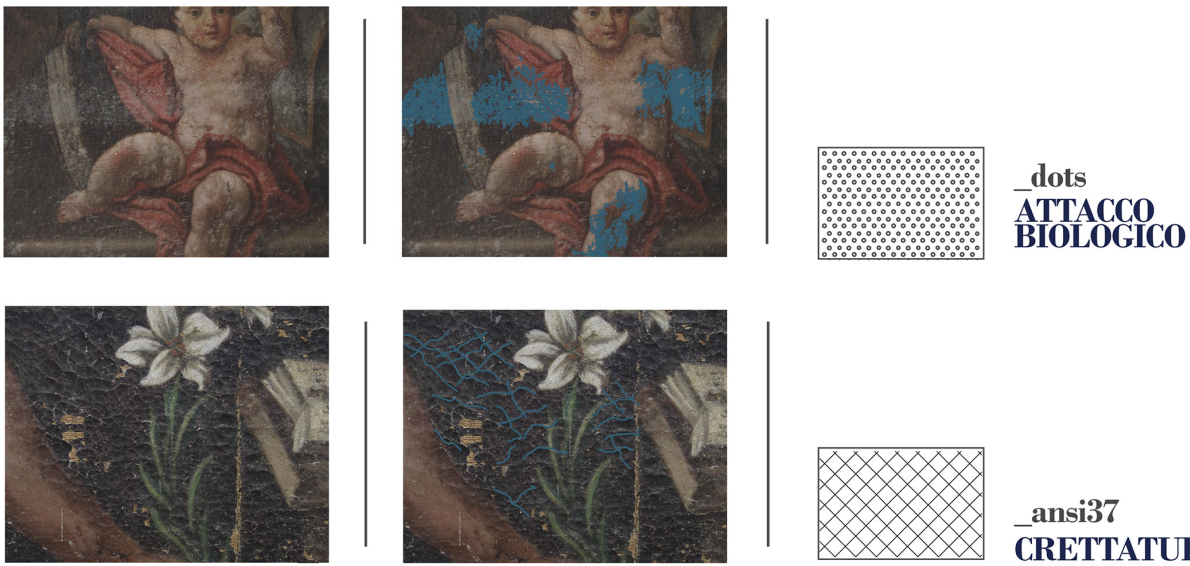

ansi37

CRETTATURA

Corso di Disegno 2 | A.A. 2018/2019 
A similar procedure has been applied for the realization of a descriptive legend of the executive techniques using coloured hatches.

To describe the documentation about state of conservation, it was possible to refer to the science of drawing and vector graphics. The approach is different for diagnostic documentation description. In this case it is not enough to refer to the culture of visual design, it is necessary to integrate in our sketches and models a different link and open to a dynamic multi-level documentation. The communicative tool cannot be here the drawing, but the interpretation of scientific data happens through the word that helps the restorer to define causes of degradation and possible interventions. This need can be satisfied by an online database that allows real-time connection to the data made available by the diagnosticians. In our case a QRcode combined with the survey table allows direct consultation of microinvasive investigations.

\section{Represent to preserve: the finding of a standard for mobile artistic objects}

The architect uses drawing to give shape to his projects, the restorer should take advantage of the analytical and descriptive qualities of drawing: the analytical approach is the fundamental starting point for a technical study of the object and for its deep knowledge. The science of representation offers descriptive and communicative possibilities and this gives the real possibility to make the discipline of conservation sustainable in the future. Only by communicating the results obtained, placing them within an accessible territory and making them available to those who use art every day can we say that the restorer's mission has been completed. This can only take place in the face of a systematic data collection, which follows a standardized path and regulated by the real documentation needs.

The study aims to fill the methodological gap between traditional techniques that do not involve the use of graphic sketch and digital tools for data systematization. Today the digital methods are applied to heritage in an increasingly massive way. The whole experimentation can be defined as the attempt to identify a fundamental path, through didactics, to reach the digital data conscious of its cultural value.

So, does it make sense today to still talk about drawing applied to the documentation of restoration work on movable property in a context where digital technologies represent and document every step of the work very quickly? We believe so. This paper shows how the use of traditional theory combined with a dynamic and integrated contemporary thinking allows us to take the first steps towards a sector, which has so far been little studied, but which is of fundamental importance because it concerns the documentation of our identity heritage.

There can be a radical change of direction from new educational paths. The discipline of drawing, often forgotten by conservators, can gain an important role by improving the effectiveness of teaching representative techniques applied to a moving heritage. This is possible by recalling the history of representation and incorporating the teaching of computer techniques suitable for professional objectives in the fields of conservation and restoration.

\section{Notes}

[1] Drawing 2 - School of Conservation and Restoration University of Urbino Carlo Bo, A.A. 2018/2019.

\footnotetext{
References

Colistra Daniele (20 I I). Novanta idee in attesa di Layout. In Salerno Rossella (a cura di). Teorie e tecniche della rappresentazione contemporanea. Sant'Arcangelo di Romagna (RN): Maggioli Editore, 201 I, pp. 1 7-32.

D'Acunto Giuseppe, 2012. Complessità e configurazione. Disegno e geometria delle forme architettoniche. Venezia: Geometria Disegno Immagine, Libreria Editrice Cafoscarina.

De Mattia Francesco, Zaccaria, Ambrosi Angelo (1994). Geometria e percezione nei metodi di rappresentazione grafica. Quaderni dell'istituto di disegno-politecnico Bari. Bari: Edipuglia.
} 
De Rubertis Roberto ( 1994). II disegno dell'architettura. Roma: Carrocci Editore.

Docci Mario, Migliari Riccardo (1992). Geometria Descrittiva e Scienza della rappresentazione. Incontro di studi su geometria e percezione nei metodi di rappresentazione grafica, Bari 23-24 settembre 1992. Bari:Edipuglia.

Docci Mario, Gaiani Marco, Maestri Diego (201 I). Scienza del disegno. Roma: Cittastudi.

Filippa Monica (a cura di) (20I2). Elogio della teoria - In praise of theory. Identità delle discipline del disegno e del rilievo - The fundamentals of the disciplines of representation and survey. Atti del $34^{\circ}$ Convegno Internazionale dei Docenti delle Discipline della Rappresentazione. Roma 13-15 settembre 2012. Roma: Gangemi.

Mazzetti Carlo (1975). Il disegno: analisi di un linguaggio. Castions de mura (UD): La Goliardica.

Migliari Riccardo (2004). Disegno come Modello. Riflessioni sul disegno nell'era informatica. Bologna: Edizioni Kappa.

Migliari Riccardo (20I2). Elogio della teoria - In praise of theory. In Filippa Monica (a cura di) (20I2). Elogio della teoria - In praise of theory. Identità delle discipline del disegno e del rilievo - The fundamentals of the disciplines of representation and survey. Atti del $34^{\circ}$ Convegno Internazionale dei Docenti delle Discipline della Rappresentazione. Roma I3- I5 settembre 20 I2. Roma: Gangemi.

Rossi Michela (2006). II segno e la forma. Grammatica grafica per l'architettura. Fidenza (PR): Mattioni DRR-Quaderni per la didattica e la ricerca della Facoltà di Architettura.

Russo Jacopo (2008). Degrado dei materiali lapidei: proposta di simbologia grafica. In Carbonara Giovanni. Trattato di restauro architettonico - Secondo aggiornamento. Milano: UTET.

Salerno Rossella (a cura di) (20I I). Teorie e tecniche della rappresentazione contemporanea. Sant'Arcangelo di Romagna (RN): Maggioli Editore.

Spallone Roberta (2012). Rappresentazione e progetto. La formalizzazione delle convenzioni del disegno architettonico. Alessandria: Edizioni dell'Orso.

Strollo Rodolfo Maria (2008). Rappresentazione e formazione. Tra ricerca e didattica. Roma: Aracne editrice.

\section{Authors}

Francesca Gasparetto, University Politecnica delle Marche, fnc.gasparetto@gmail Laura Baratin, University of Urbino Carlo Bo, laura.baratin@uniurb.it

To cite this chapter: Gasparetto Francesca, Baratin Laura (2020). La rappresentazione del restauro. Quale ruolo per il disegno documentativo di un intervento conservativo/The representation of restoration process. What role for the documentary drawing of a conservative intervention. In
Arena A., Arena M., Brandolino R. G., Colistra D., Ginex G., Mediati D., Nucifora S., Raffa P. (a cura di). Connettere. Un disegno per annodare e tessere. Arena A., Arena M., Brandolino R.G., Colistra D., Ginex G., Mediati D., Nucifora S., Raffa P. (a cura di). Connettere. Un disegno per annodare e tessere.
Atti del $42^{\circ}$ Convegno Internazionale dei Docenti delle Discipline della Rappresentazione/Connecting. Drawing for weaving relationships. Proceedings of the 42th International Conference of Representation Disciplines Teachers. Milano: FrancoAngeli, pp. 467-484 